Article

\title{
Investigation on Farmland Abandonment of Terraced Slopes Using Multitemporal Data Sources Comparison and Its Implication on Hydro-Geomorphological Processes
}

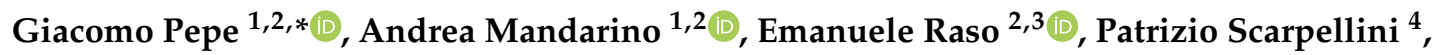 \\ Pierluigi Brandolini ${ }^{1}$ (i) and Andrea Cevasco ${ }^{1}$ \\ 1 Department of Earth, Environmental and Life Sciences, University of Genova, Corso Europa 26, \\ 16132 Genova, Italy \\ 2 Geoscape Soc. Coop., Geo-Environmental Consulting, Via Varese 2, 16122 Genova, Italy \\ 3 Department of Earth Sciences, Environment and Resources, Federico II University of Napoli, \\ Complesso Universitario Monte Sant'Angelo, Building L1, Via Cinthia, 80126 Napoli, Italy \\ 4 Ente Parco Nazionale delle Cinque Terre, Via Discovolo snc, Manarola, 19017 Riomaggiore, Italy \\ * Correspondence: giacomo.pepe@unige.it; Tel.: +39-01-0353-8206
}

Received: 9 July 2019; Accepted: 25 July 2019; Published: 2 August 2019

\begin{abstract}
This paper presents a quantitative multi-temporal analysis performed in a GIS environment and based on different spatial information sources. The research is aimed at investigating the land use transformations that occurred in a small coastal terraced basin of Eastern Liguria from the early 1950s to 2011. The degree of abandonment of cultivated terraced slopes together with its influence on the distribution, abundance, and magnitude of rainfall-induced shallow landslides were accurately analysed. The analysis showed that a large portion of terraced area $(77.4 \%)$ has been abandoned over approximately sixty years. This land use transformation has played a crucial role in influencing the hydro-geomorphological processes triggered by a very intense rainstorm that occurred in 2011. The outcomes of the analysis revealed that terraces abandoned for a short time showed the highest landslide susceptibility and that slope failures affecting cultivated zones were characterized by a lower magnitude than those which occurred on abandoned terraced slopes. Furthermore, this study highlights the usefulness of cadastral data in understanding the impact of rainfall-induced landslides due to both a high spatial and thematic accuracy. The obtained results represent a solid basis for the investigation of erosion and the shallow landslide susceptibility of terraced slopes by means of a simulation of land use change scenarios.
\end{abstract}

Keywords: agricultural terraces; cadastral map; cadastral register; farmland abandonment; GIS; land use changes; shallow landslides; terraced slopes

\section{Introduction}

Temporal variation in land use and land cover (LULC) represents one of the main environmental factors controlling the occurrence of natural phenomena like landslides [1,2] and floods [3-6]. In particular, LULC can influence the distribution, abundance, and magnitude of the hydrological processes of shallow landsliding. In the last twenty years, numerous studies have considered the effects of changing land use scenarios in the analysis of landslide susceptibility [7-12], hazard [13,14], and risk $[15,16]$.

LULC modifications directly or indirectly induced by human activity, such as extensive deforestation practices or road and constructions built in hazardous zones, often produce the most severe 
landslide-related consequences. For instance, forest logging can decrease the positive hydro-mechanical effects of vegetation (e.g., soil reinforcements by roots, reduction of rainfall infiltration and pore water pressure by evapotranspiration processes) $[17,18]$, causing an increase in the proneness of slopes to erosion phenomena like mass movements and runoff $[19,20]$. Among the indirect human-related land use modifications, the abandonment of farming areas can be considered by far one of the most relevant [21-27]. In Europe, due to the significant social and economic changes which occurred after the Second World War [28], many hilly and mountainous regions have experienced severe and accelerated slope degradation issues led by farmland abandonment [29-34]. Slope degradation in conjunction with extreme rainfall can produce a significant growth in susceptibility to erosion and landslide phenomena [35-42]. Moreover, abandoned slopes may become source of risk scenarios when located in the proximity of urban areas $[43,44]$.

The negative effect of farmland abandonment on slope stability can be especially important in terraced landscapes. It is widely known from technical literature that terraces concur to improve slope stability by reducing the overall slope gradient and by regulating water infiltration and runoff [45-50]. However, due to agricultural abandonment, the basic components of terraced systems, namely dry-stone walls and complementary drainage structures, are no longer adequately maintained and managed, causing the efficiency of the hydrological and retaining functions to decrease. Accordingly, agricultural terraces become more vulnerable and therefore highly susceptible to collapses and failures [51-55]. Many studies addressed that the degree of abandonment is a crucial factor in regulating the susceptibility of terraced slopes to be affected by rainfall-induced landslides [11,56-59].

Unlike other environmental landslide predisposing factors like geology, geomorphology or soil types, LULC is not a static factor since it may undergo significant variations over time [1]. Consequently, for landslide hazard and risk assessment purposes this causal factor should be regularly updated according to LULC changes in a specific area. The analysis of past land use settings and modifications is therefore essential to assess landslide susceptibility of an area as well as to estimate the future occurrence of slope failures. As reported by some authors [15,60], in order to perform a reliable analysis of land use changes it is essential to correctly determine where these modifications occurred and their rates. Nowadays, the availability of digital tools for managing spatial information such as geographical information systems (GIS) together with remote sensing techniques represents a very useful way of investigating LULC changes over large areas. These methods allow for the production of multi-temporal LULC maps and LULC change maps that are fundamental data sets in the framework of both landslide zoning and GIS-based modelling of landslide susceptibility and hazard [1,2]. In order to create past LULC thematic maps of an area, the interpretation of historical aerial photos is usually performed. However, also ancillary data can be a precious data source. Old cadastral maps, for example, are often the only available source of information about past land use setting. Cadastral data can cover several time frames often providing information at a very detailed scale. There are several examples about the use of cadastral maps to analyse spatial and temporal variation in land use. Nevertheless, these studies are usually focused on analysing socioeconomic or political factors behind land use changes and their consequences on landscape, ecology and biodiversity [61-66]. Moreover, cadastral databases frequently represent basic elements in landslide risk analysis [1], even though very few researches [67] have used cadastral data to understand the impact of landslides in response to land use transformations.

Terraced slopes are one of the most relevant morphological features of the Ligurian landscape (north-western Italy). This region is predominantly hilly and mountainous and since the early centuries of the Middle Ages wide extensions of natural slopes were terraced to allow cultivation practices. Nowadays, a significant percentage of traditional agricultural terraces is currently abandoned due to accelerated socioeconomic transformations occurred during the last century $[68,69]$.

This paper describes the use of different multitemporal spatial information aimed at quantifying land use modifications affecting agricultural terraced slopes in a small coastal catchment located within the Cinque Terre National Park (eastern Liguria, north-western Italy). The selected study area 
is indicative of the farmland abandonment spread throughout the entire Liguria region. Historical LULC maps were derived from old cadastral maps and aerial photographs of the study area and they were compared with the current land use conditions to make an accurate estimate of the degree of abandonment of terraces over the last sixty years. Subsequently, the current spatial pattern of the land use conditions of terraced slopes was analysed with respect to the distribution of the shallow landslides triggered by a very intense rainfall event occurred on 25 October 2011 [11,70]. The objective of this study is twofold. On the one hand, the aim is to verify the usefulness of cadastral data in understanding the impact of rainfall-induced landslides on terraced slopes. On the other hand, the aim is to further improve the knowledge about the relationship between land abandonment and shallow landslide processes.

\section{General Setting of the Study Area}

The study area is located on the easternmost sector of Liguria (northwestern Italy) and corresponds to the Vernazza catchment, the widest of several small coastal basins of the Cinque Terre area (Figure 1a). The study catchment extends for approximately $5.8 \mathrm{~km}^{2}$ and from a geological point of view it is included within a segment of the Northern Apennine that is characterized by sedimentary rocks belonging to three tectonic units (bottom to top): Tuscan Nappe, Marra unit, and Canetolo complex [71]. The Marra Unit and the Canetolo complex entirely crop out along a NW-SE oriented stretch of land that occupies the middle portion of the basin (Figure 1b). The first one is prevalently composed of marls and siltstones (Pignone Marls Fm.) while the second one respectively includes assemblages of prevailing shales with subordinate limestones and silty sandstones (Canetolo Shales and Limestones Fm.), marly limestones and calcarenitic turbidites (Groppo del Vescovo Limestones Fm.) and fine-grained sandstone turbidites (Ponte Bratica Sandstones Fm.). On the other hand, the Tuscan Nappe crops out in the majority of the basin area and chiefly consists of typical turbidites made up of sandstones and siltstones (Macigno Fm.). Overall, rock formations are arranged in a complex structural setting characterized by a large, SW-verging, overturned antiform fold and by multiple sets of tectonic discontinuities associated to the Apennine orogeny and to the Plio-Quaternary tectonic up lift [72,73].

As a result of the peculiar geo-structural setting, the study area shows the typical morphology of mountainous regions, in spite of the proximity to the sea [74]. The elevations increase rapidly moving from the coastline to the inland territory. The maximum altitudes are widespread all around the main watershed and are represented by the peaks of Mt. S. Croce (622 m), Mt. Gaginara (772 m) and Mt. Malpertuso ( $815 \mathrm{~m}$ ) (Figure 1b). The inner territory of the basin is carved by numerous small and narrow V-shaped valleys drained by a dense dendritic channel network with steep profile while the shoreline is mostly characterized by rocky cliffs [73-75]. Generally, the streams are short and show an ephemeral hydrological regime. The final reach of the main stream was diverted in the past and currently it flows partly culverted and partly through a tunnel for a total length of over $150 \mathrm{~m}$. The small V-shaped valleys are limited by steep to very steep slopes (Figure 1c,d) covered by thin veneers (thicknesses ranging between 1 and $2.5 \mathrm{~m}$ on average) of eluvial-colluvial deposits [11,76] that in the past were largely reworked by local inhabitants in order to build agricultural terraces, mainly cultivated with vineyards and olive groves [74,77]. The resulting terraced landscape is now a worldwide-known tourist attraction declared since 1997 as "UNESCO World Heritage" for its high scenic and cultural value and since 1999 as a national park due to its environmental and naturalistic relevance. 


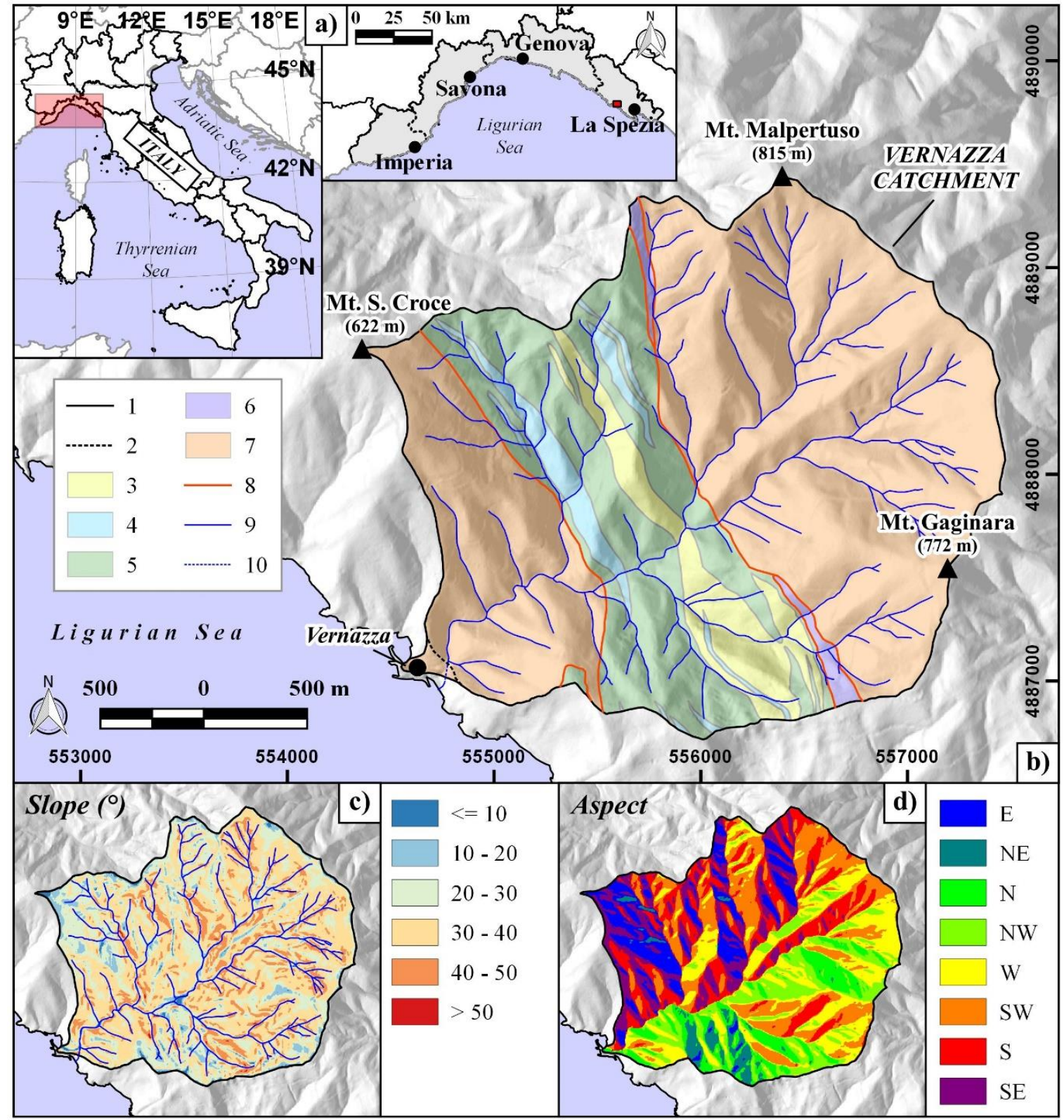

Figure 1. (a) Location of the study area; (b) Geologic map of the Vernazza basin (redrawn and modified from [71]): 1, Vernazza catchment divide; 2, downstream-most limit of the investigated catchment 3, Ponte Bratica sandstones Fm.; 4, Groppo del Vescovo limestones Fm.; 5, Canetolo shales and limestones Fm.; 6, T. Pignone marls Fm.; 7 Macigno Fm.; 8, main tectonic features (e.g., direct and reverse faults, overthrusts); 9, hydrographic network; 10, tunnelled reach of the main stream; (c) slope map of the Vernazza basin; (d) aspect map of the Vernazza basin (derived from $5 \mathrm{~m}$ cell-size DEM, source: Geoportale Regione Liguria).

The current land use setting was analyzed through recent researches [78]. Natural areas, prevalently including woods and scrub, cover approximately $50 \%$ of the study area and are mostly distributed along the upper portions of the catchment. The remaining $50 \%$ of the basin, encompassing the middle and lower zones of the catchment, is entirely covered by terraced slopes characterized by different land uses and degrees of abandonment. However, it is relevant to note that only about $8 \%$ of terraced slopes is still cultivated at present time [78]. Urban areas represent a very small portion of the basin and they mainly coincide with the Vernazza village, which is settled on the downstream portion of the valley floor. 
The morphological features deeply influence the local climate setting. The orientation of the main watershed parallel and very close (approximately $3 \mathrm{~km}$ ) to the coastline produces a topographic effect that locally increases the effects of the typical Mediterranean climate. The average annual temperature is about $15^{\circ} \mathrm{C}$ while the average annual precipitation is around $1000 \mathrm{~mm}$ [35]. Generally, summers are warm and dry whereas winters are somewhat mild. Rainfalls are on average more abundant between the end of summer and the beginning of winter, when very intense and strongly localized rainstorms can often affect this coastal sector of the Liguria Region [35,79]. On 25 October 2011, one of these extreme rainfall events seriously hit the western sector of the Cinque Terre area and especially the Vernazza catchment. Widespread erosion processes were triggered together with several hundred shallow landslides often evolving rapidly into flow-like ones [11].

\section{Materials and Methods}

This research consists of a quantitative multi-temporal analysis performed in a GIS environment. This work has been carried out in three steps (Figure 2). In the first step, historical and recent aerial photos have been used as mapping basis to obtain LULC data of the study area in 1954 and 2011, respectively.

\begin{tabular}{|c|c|c|}
\hline $\begin{array}{l}\text { Data sources } \\
\text { Period }\end{array}$ & $\begin{array}{c}\text { Aerial photographs } \\
1954\end{array}$ & $\begin{array}{l}\text { Landslides inventory } \\
\qquad 2011\end{array}$ \\
\hline \multirow[t]{4}{*}{ Phase 1} & \multicolumn{2}{|c|}{ LULC mapping } \\
\hline & LULC classes for $\underline{1950-1952}$ and $\underline{1954}$ : & LULC classes for 2011 (within 1954 AGR): \\
\hline & 1) Agricultural area; & 1) Cultivated terraced area; \\
\hline & 2) Natural and semi-natural area; & 2) Abandoned terraced area; \\
\hline \multirow[t]{2}{*}{ Phase 2} & \multicolumn{2}{|c|}{ LULC analysis } \\
\hline & LULC data comparison: 1950-52 VS 1954 & LULC change detection: 1954 (AGR) VS 2011 \\
\hline \multirow[t]{2}{*}{ Phase 3} & \multicolumn{2}{|c|}{ Slope instability processes distribution analysis } \\
\hline & & 2011 LULC (within 1954 AGR) VS 2011 landslides \\
\hline
\end{tabular}

Figure 2. Workflow sketch summarizing the considered data sources and the sequence of performed methodological phases. The dotted lines refer to the data sources and indicate which of them are involved in each phase. Blue- and green-highlighted elements in Phase 1 refer to the Phase 2 components; LULC, land use and land cover; AGR, agricultural area.

In the second step, the 1954 LULC map and the cadastral maps dating back to the early 1950s were brought into comparison to analyze whether cadastral data were geometrically accurate and thematically comparable. Subsequently, an overlay analysis among the 1954 LULC map and the recent land use setting have been performed to investigate the farmland abandonment of terraced slopes. These analyses did not take into account the downstream-most small portion of the catchment corresponding to the historical center of Vernazza since already totally urbanized in the 1950s. Eventually, in the third step the spatial distribution of the shallow landslides triggered by the 25 October 2011 rainstorm was analysed with respect to LULC changes occurred in agricultural areas of 1954.

\subsection{Data Sources}

This research is based on several types of data sources providing information on both past and recent LULC settings and hydro-geomorphological processes that affected the study area (Figure 2). To map the past LULC, the aerial photographs from the "GAI flight" were integrated in a GIS environment through a georeferencing procedure. This data, approximately at 1:60,000 scale and dating back 
to 14 September 1954, represents the first stereoscopic photographs depiction covering the whole Italian territory.

To analyze recent LULC, high-resolution orthophotos (ground resolution varying between $3 \mathrm{~cm}$ and $50 \mathrm{~cm}$, according to elevation) were used: the original aerial photos were taken by the Air Service of Remote Sensing and Monitoring of Civil Protection of Friuli Venezia Giulia Regional Administration (11 November 2011 flight) just a few days after the catastrophic rainfall event occurred on 25 October 2011. Furthermore, land use information deriving from cadastral maps dating back to early 1950s were considered. These maps were drawn at large scale (from 1:2000 up to 1:500) in order to provide a very detailed spatial information since the associated database reported the classification in terms of LULC for each land parcel. In particular, we used a vector layer made up of polygons representing land parcels which was provided by the Cinque Terre National Park and derived from old cadastral maps.

Lastly, a detailed inventory of rainfall-induced shallow landslides prepared by Cevasco et al. [78] after the 25 October 2011 event was used. It is relevant to point out that in this study only shallow landslides that affected terraced slopes cultivated in 1954 were selected.

\subsection{Land Use Mapping}

In a GIS environment, the polygons representing land use units were manually mapped at 1:2500 scale through aerial-photos interpretation to obtain the map of the Vernazza catchment depicting the LULC conditions in 1954 (Figure 2). Three main land use classes were visually identified: urban areas (URB), natural and semi-natural areas (NAT) and agricultural areas (AGR). NAT include woodlands, shrubs and zones occupied by herbaceous vegetation. Considering the morphological features of the study area, AGR can be assumed as the extent of the cultivated terraced slopes in 1954.

Subsequently, we produced a land use map using cadastral data temporally referring to the early 1950s. The land use categories used for this second map were the same as the ones adopted in the interpretation of historical aerial photos. Therefore, land use information related to every parcel was reclassified according to the aforementioned three major land use classes, in order to compare heterogeneous data. In detail, the following cadastral parcels were considered as agricultural areas: orchards, arable lands, vineyards, olive groves, pastures and meadows. All patches reported as tall forests and coppice woods were instead included into natural and semi-natural areas while buildings and rural buildings were grouped as urban areas. The parcels belonging to the same class were then dissolved and the areas not covered by parcels (ND), substantially corresponding to state-owned plots of land, were extracted.

Eventually, by using the 2011 high-resolution aerial orthophotos, 1954 agricultural areas (1954 AGR) were classified into three major LULC categories reflecting their recent land use conditions: urban areas, abandoned terraced areas and cultivated terraced areas (Figure 2). In this phase, a number of sub-categories were also defined in order to perform a more detailed analysis. In particular, following the classification adopted by Cevasco et al. [78], abandoned terraced slopes were subdivided into abandoned terraced slopes with poor (ATP) and dense cover (ATD) according to the degree of vegetation development [78]. The former show herbaceous cover or shrubs and can be assumed as abandoned for a short time (less than 25-30 years). The latter have been abandoned for longer time (more than 25-30 years) resulting prevalently occupied by forest tree species. Furthermore, the cultivated zones were divided into two land use sub-classes labelled as areas mostly presenting vineyards (CTV) and olive groves (CTO), respectively.

\subsection{Data Processing}

The 1954 and the cadastral-based LULC maps were first compared through an overlapping procedure in order to quantify the differences and subsequently to validate the land use information attached to cadastral data. Afterward, to quantify and locate precisely the land use transformations affecting the agricultural areas dated 1954, land use data referred to the 2011 were analyzed by computing the extent of each land use class and sub-class (Figure 3). 


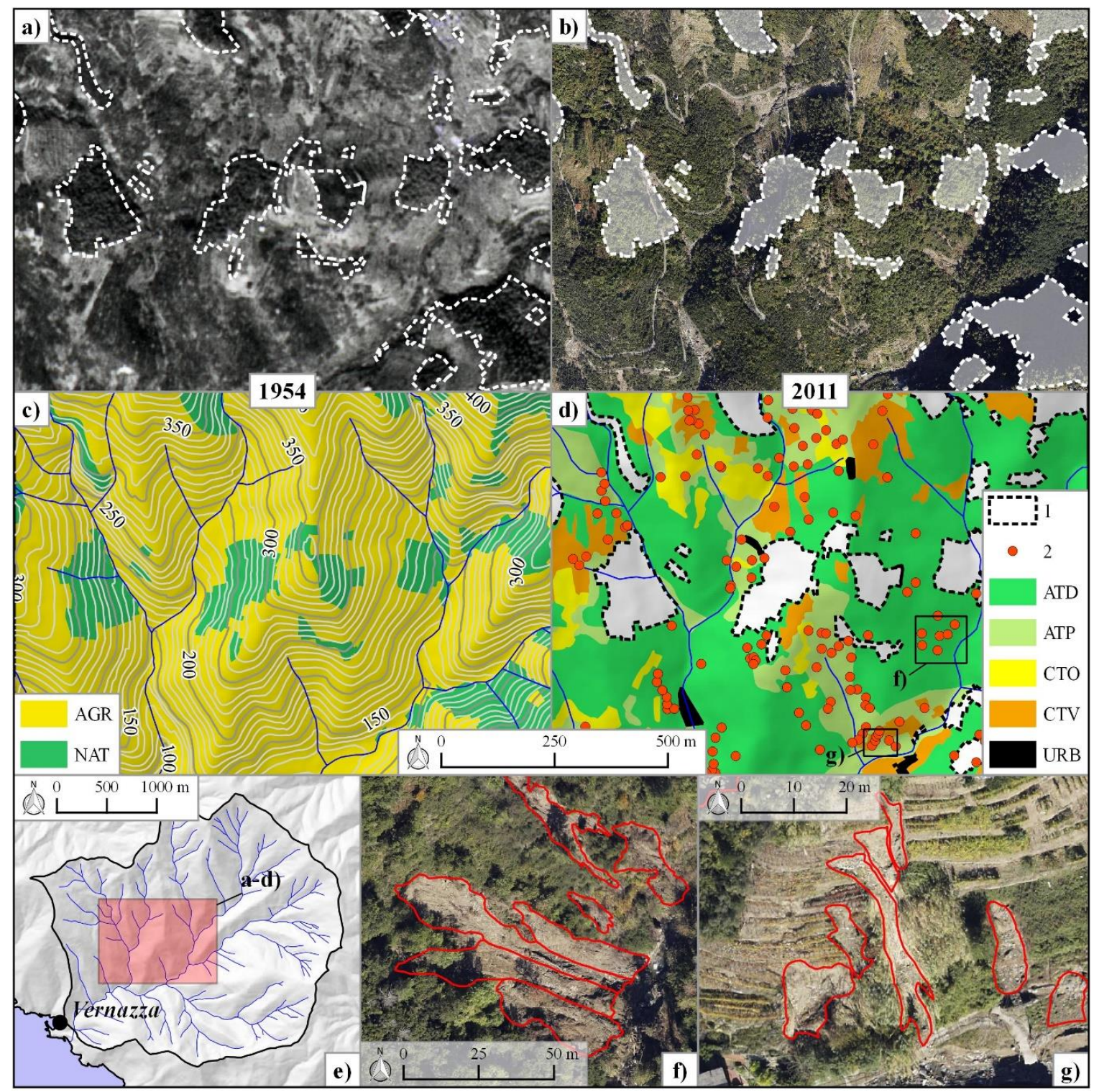

Figure 3. Data sources and derived land use and land cover (LULC) maps: (a) Aerial photograph dated 1954; (b) Orthophoto dated 2011; (c) 1954 LULC map; (d) 2011 LULC map in 1954 agricultural area; (e) Location of (a) to (d) sketch maps; (f,g) examples of landslides triggered on 25 October 2011. The white dashed line in (a) separates agricultural and natural and semi-natural area. The white transparent polygons in (b) represent natural and semi-natural areas in 1954. The red lines in (f,g) highlight the perimeter of landslides triggered on abandoned and cultivated terraced slopes, respectively. AGR, agricultural area; NAT, natural and semi-natural area; 1, natural and semi-natural areas in 1954; 2, 2011 landslide sources; ATD, abandoned terraced slope with dense cover; ATP, abandoned terraced slope with poor cover; CTO, cultivated olive grove; CTV, cultivated vineyard; URB, urban area.

Through the last step of the analysis, we investigated the relationships between the outlined land use changes that affected agricultural lands over the last 60 years and the distribution of shallow landslides triggered by the 25 October 2011 rainstorm. Landslide polygons were superimposed on the 2011 land use map and for each LULC category the area affected by landslides was calculated. Furthermore, we digitized a point at the center of every landslide crown to compute the number of slope instability processes that were triggered in each land use category.

Lastly, the landslide area related to each land use class was divided to the total area of that land use type to assess the landslide index (LI). 


\section{Results}

\subsection{Land Use Changes Analysis}

The LULC map produced through the interpretation of aerial photos shows that in $195459.1 \%$ of the total basin area $\left(5.8 \mathrm{~km}^{2}\right)$ was made up of natural and semi-natural areas, followed by cultivated agricultural lands (40.8\%) and urban areas (0.1\%) (Table 1; Figure 4$)$. The majority of NAT lands almost totally covered the upper portion of the catchment, approximately starting from $400 \mathrm{~m}$ of altitude depending on slope aspect, while the remaining ones prevalently extended over the middle portions placed close to the main watershed (Figure 4a). On the other hand, farmland areas (i.e., AGR) diffusely covered the middle part of the catchment whereas they predominated in the lower part. Eventually, the urban areas mainly consisted of the man-made structures belonging to the Vernazza hamlet.

Table 1. Summary of historical land use/land cover (LULC) setting of the Vernazza catchment (AGR, agricultural area; NAT, natural and semi-natural area; URB, urban area; ND, no data).

\begin{tabular}{ccccc}
\hline \multirow{2}{*}{ LULC } & \multicolumn{2}{c}{$\mathbf{1 9 5 4 - F r o m ~ A e r i a l ~ P h o t o s ~}$} & \multicolumn{2}{c}{ Early 1950s-From Cadastral Data } \\
\cline { 2 - 5 } & $\mathbf{\%}$ & $\mathbf{k m}^{\mathbf{2}}$ & $\mathbf{\%}$ & $\mathbf{k m}^{\mathbf{2}}$ \\
\hline NAT & 59.1 & 3.40 & 59.7 & 3.44 \\
AGR & 40.8 & 2.35 & 36.4 & 2.10 \\
URB & 0.1 & 0.01 & 0.90 & 0.05 \\
ND & - & - & 3.0 & 0.17 \\
\hline
\end{tabular}
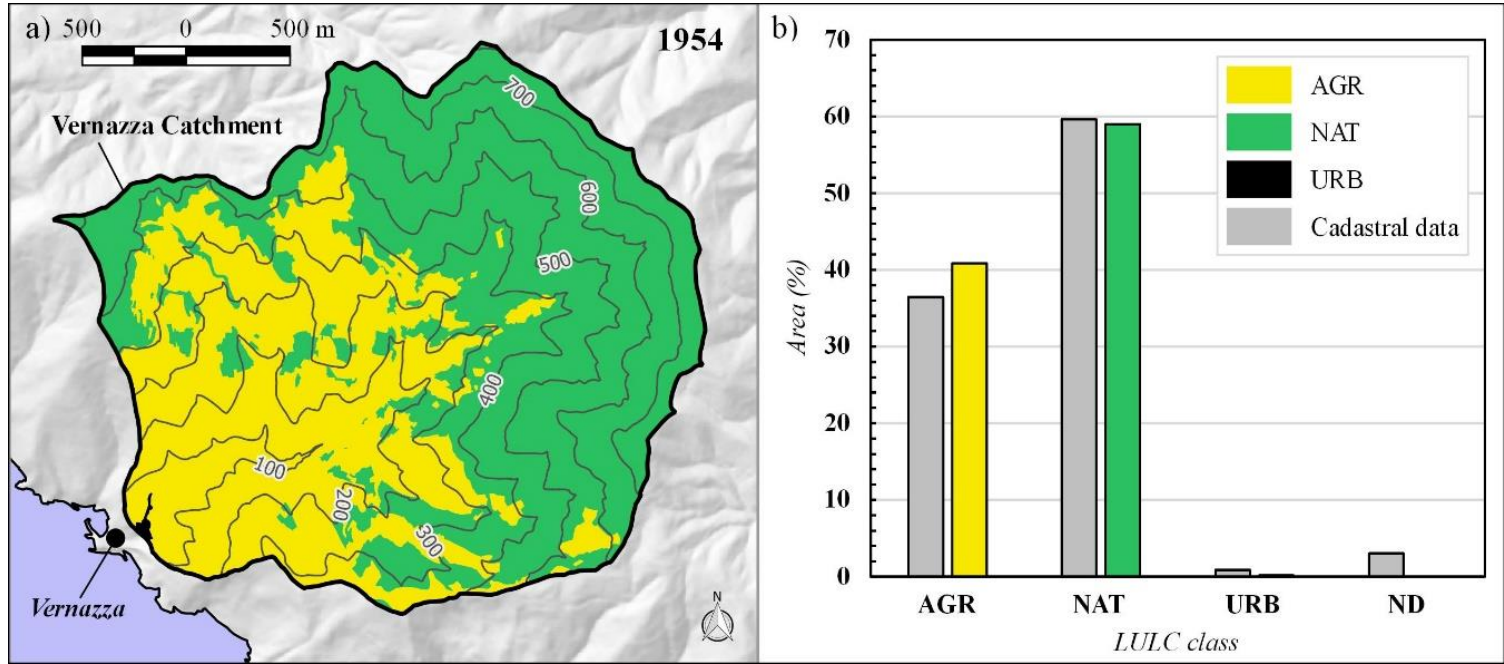

Figure 4. 1954 land use/land cover (LULC) setting of the Vernazza catchment. (a) LULC map derived from the 1954 aerial photographs; (b) Area in percentage for each LULC class. Colored columns are referred to (a) while grey columns indicate the cadastral-derived area for each LULC class; AGR, agricultural area; NAT; natural and semi-natural area; URB, urban area; ND, no data.

The results of the cadastral-based land use mapping lead to a very similar LULC setting (Table 1). In fact, the study catchment showed a prevalence of NAT (59.7\%), followed by AGR (36.4\%) and lastly by urban areas $(0.9 \%)$ while a remaining $3 \%$ of the basin resulted substantially occupied by state-owned areas (ND) (Table 1; Figure 4b). By comparing the 1954 LULC map with the one obtained through cadastral data, a very slight difference was detected as highlighted by an overlapping degree of approximately $96 \%$. Moreover, it is interesting to note that cadastral maps showed a high land-property fragmentation within the study basin, where approximately 7200 parcels were identified with an average parcel size of about $775 \mathrm{~m}^{2}$. However, the density of cadastral parcels resulted further higher in agricultural areas, where the average parcel size was $430 \mathrm{~m}^{2}$. Therefore, cadastral data allow to obtain spatial information at higher detail, greatly improving land use information obtained from 
aerial-photo interpretation. In fact, according to cadastral database, natural and seminatural areas can be mainly subdivided into tall forests $(71 \%)$ and coppice woods $(29 \%)$. On the other hand, agricultural lands consist of pastures and meadows (13\%), orchards/arable lands (23.5\%), olive groves (24\%) and vineyards (39.5\%). These results highlight the importance of agriculture activities in the early 1950s and they make possible analysis of both the distribution and extent of cultivated terraced slopes in the study area.

The main changes experienced between 1954 and 2011 by agricultural areas are summarized in Table 2 and Figure 5. It is relevant to note that over approximately sixty years a large portion of agricultural terraced slopes $(77.4 \%)$ has been abandoned while only a small percentage $(21.1 \%)$ remained cultivated. In detail, $19 \%$ of cultivated terraced slopes have become ATP while $58.4 \%$ turned into ATD (Table 2; Figure 5b). Terraced slopes that have been kept cultivated mainly consist of CTV $(15.3 \%)$ and CTO (5.8\%) whereas URB category (1.5\%) includes anthropic structures due to urban sprawl of the Vernazza hamlet together with the main rural building settlements distributed in the inland portions of the catchment. It is interesting to point out that cultivated terraces correspond to about $9 \%$ of the whole study basin. Currently, such agricultural lands are scattered in small patches, often located in the proximity of roads and/or rural settlements.

Table 2. Summary of land use/land cover (LULC) setting of the 1954 agricultural area in 2011 (ATD, abandoned terraced slope with dense cover; ATP, abandoned terraced slope with poor cover; CTO, cultivated olive grove; CTV, cultivated vineyard; URB, urban area).

\begin{tabular}{ccc}
\hline \multirow{2}{*}{ LULC } & \multicolumn{2}{c}{$\mathbf{2 0 1 1 - F r o m ~ A e r i a l ~ P h o t o s ~}$} \\
\cline { 2 - 3 } & $\mathbf{\%}$ & $\mathbf{k m}^{\mathbf{2}}$ \\
\hline ATD & 58.4 & 1.38 \\
ATP & 19.0 & 0.45 \\
CTO & 5.8 & 0.14 \\
CTV & 15.3 & 0.36 \\
URB & 1.5 & 0.03 \\
\hline
\end{tabular}
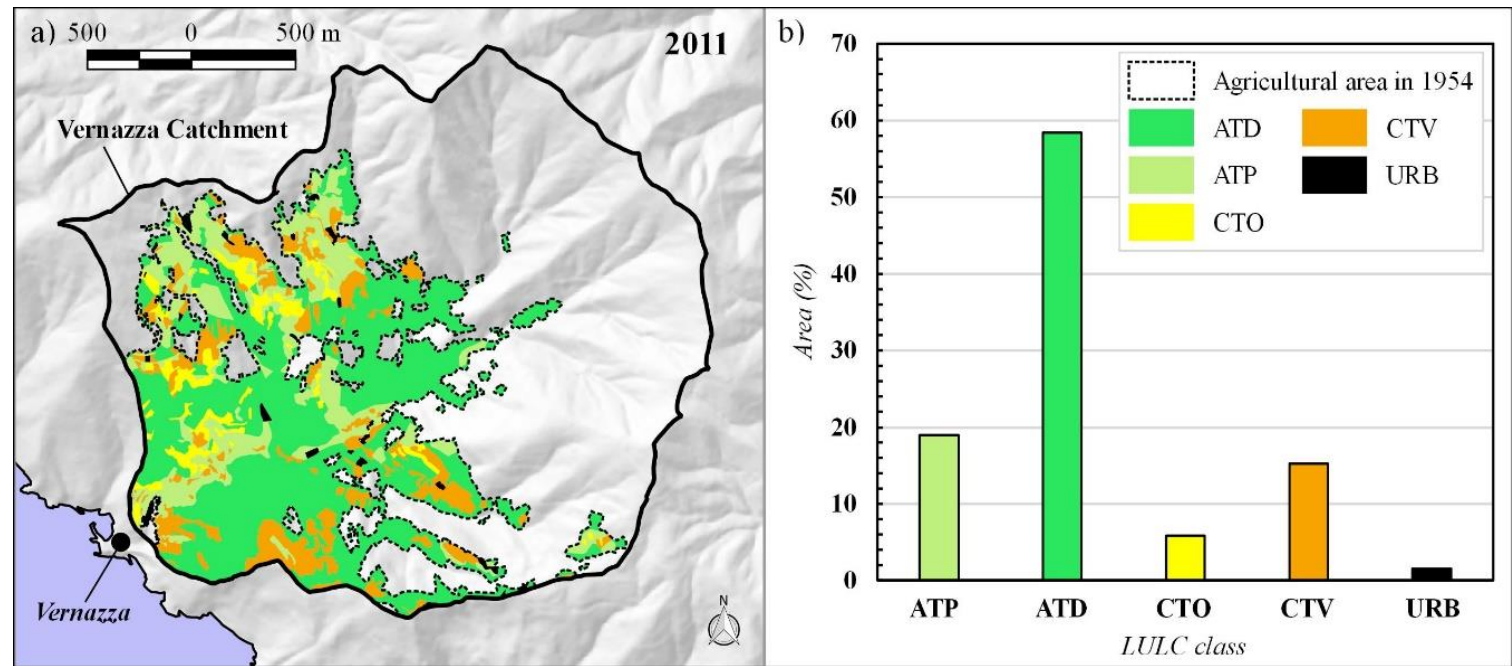

Figure 5. Land use/land cover (LULC) setting of the 1954 agricultural area in 2011. (a) LULC map. (b) Area in percentage of each LULC class; ATD, abandoned terraced slope with dense cover; ATP, abandoned terraced slope with poor cover; CTO, cultivated olive grove; CTV, cultivated vineyard; URB, urban area.

\subsection{Relationship between Rainfall-Induced Shallow Landslides and Farmland Abandonment}

After the disastrous rainstorm occurred on 25 October 2011, 364 shallow landslides were mapped by Cevasco et al. [78] through visual analysis of aerial orthophotographs and geomorphological surveys. 
Overall, GIS analysis revealed that 295 of these rainfall-induced landslides have been triggered over agricultural terraced areas dated 1954 while nine landslides run-out through them from neighboring zones. The smallest slope failure covered a surface of a few square meters, the largest one covered $5376 \mathrm{~m}^{2}$ while the average landslide size was estimated to be $216 \mathrm{~m}^{2}$. The corresponding total area affected by landslides is $6.48 \times 10^{-2} \mathrm{~km}^{2}$, representing $2.75 \%$ and $1.12 \%$ of AGR 1954 and of the entire Vernazza catchment, respectively. Considering that the extent of 1954 cultivated slopes was about $2.35 \mathrm{~km}^{2}$, the average landslide density in this land use class is 125 landslides $/ \mathrm{km}^{2}$. Generally, in 2011 the highest amount of rainfall-induced instability phenomena (68.8\%) occurred on abandoned agricultural lands, which are the most represented land cover class $(77.4 \%)$, while $31.2 \%$ of slope instabilities affected still cultivated terraced slopes (21.1\%). In particular, as can be seen in Figure 6, most of the landslide crowns (39\%) affected ATD while a lower percentage $(29.8 \%)$ of the landslides has been triggered on ATP, representing $58.4 \%$ and $19.0 \%$ of 1954 agricultural areas, respectively. An important amount of landslide crowns was also detected in CTV $(23.7 \%)$, while considerably lower landslide scars affected CTO (7.5\%), which represent $15.3 \%$ and $5.8 \%$ of the areas that were cultivated in 1954, respectively. Furthermore, it was observed that landslides triggered on cultivated areas are generally lower in magnitude than those occurred on abandoned ones. In detail, the average extent of landslides that occurred on CT $\left(70 \mathrm{~m}^{2}\right)$ is about half of those that occurred on ATP $\left(140 \mathrm{~m}^{2}\right)$ and ATD $\left(145 \mathrm{~m}^{2}\right)$. The most important observations come from the analysis of the landslide index, which represents the landslide area in each land use class in relation to the area of the considered land use class. The highest LI value was obtained for ATP (5.5\%). Significant LI values were also associated to CTV $(2.85 \%)$ and CTO (2.67\%) whereas it was significantly lower for ATD $(1.85 \%)$.

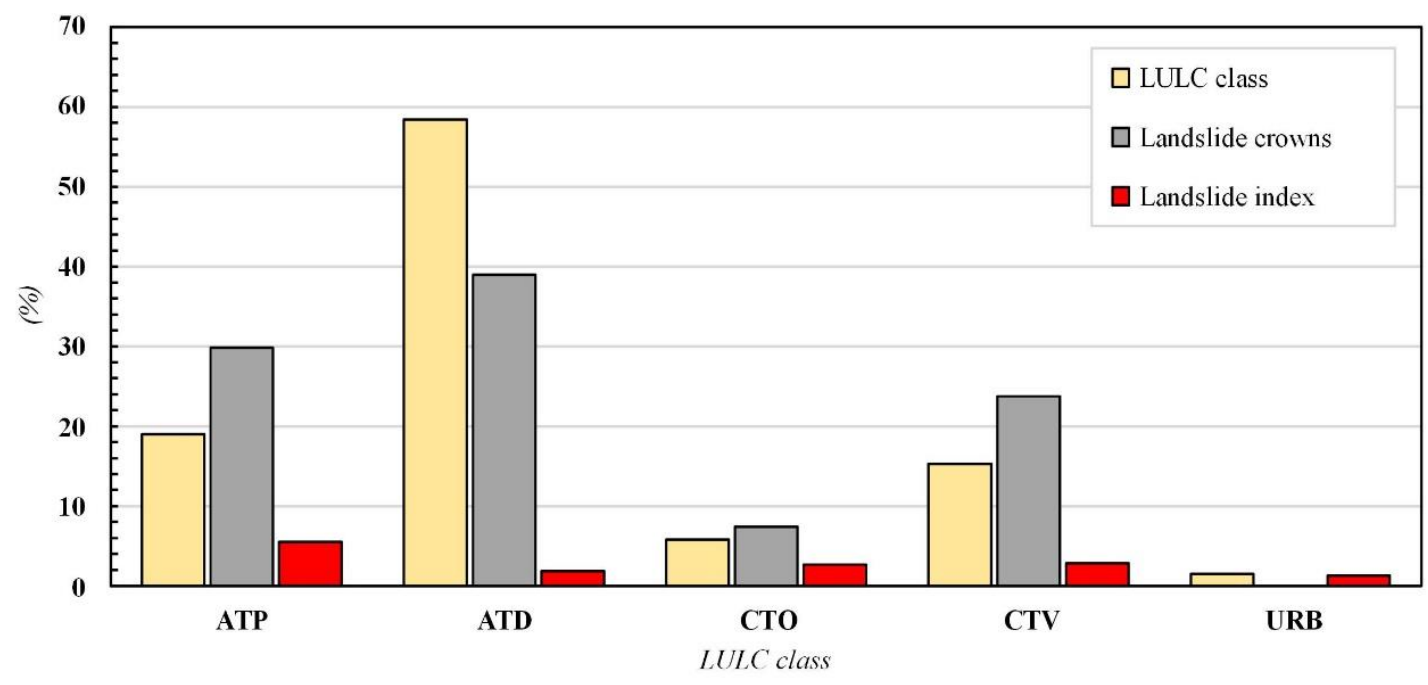

Figure 6. Histograms showing the relationships between the percentage of landslide crowns and of the Landslide Index with respect to land use/land cover of 2011 (LULC 2011); ATP, abandoned terraced slopes with poor cover; ATD, abandoned terraced slopes with dense cover; CTO cultivated olive groves; CTV, cultivated vineyards; URB, urban areas.

\section{Discussion}

The most important landscape transformations experienced by the Cinque Terre territory are directly or indirectly related to human action. Due to an impressive work of deforestation, reworking of eluvial-colluvial deposits, and building of dry-stone masonries, which has been carried out since the early centuries of the Middle Ages, terraced slopes have become the leading morphological peculiarity of the local landscape. During this time frame, farmland terraces have played a crucial role both as a source of livelihoods and as a regulating factor of hydro-geomorphological processes. According to Terranova et al. [80], the maximum extent of cultivated terraced slopes can be dated back to the second half of the 19th century. Starting from this period, terrace cultivation and maintenance have 
suffered from the first interruptions, which were mainly driven by scarce agricultural incomes that in turn led to the initiation of the earliest depopulation trends. However, the major decline of farmland started after the Second World War [80-82]. This period represents the so-called "Italian economic boom" that was the main cause of the largest exodus from agricultural lands [28]. On the other hand, the first decade of the new millennium can be assumed as the maximum expression of farmland abandonment of hilly and mountainous zones. Therefore, in this study these two periods were selected since they can be considered of crucial relevance in analyzing the effect of farmland abandonment on the hydro-geomorphological dynamics of slopes.

The results of this research revealed that approximately $40 \%$ of the Vernazza catchment was occupied by cultivated, that is terraced, areas in the early 1950s, denoting that farming activities were still an important driving force of the local economy. However, it should be noted that the extent of such areas cannot be considered as the actual total surface of the basin characterized by terraced slopes. In fact, an unknown portion of the investigated basin could have been abandoned before the early 1950s, causing it to look like a natural and/or semi-natural area in 1954 due to the presence of a dense vegetation cover. This is confirmed by the results provided by Terranova et al. [80] obtained through field surveys and analysis of historical aerial photos older than early 1950 s, estimating that $51 \%$ of the whole Vernazza municipality territory (extending about $12 \mathrm{~km}^{2}$ ) could be considered as occupied by terraces, both cultivated and characterized by different levels of abandonment.

This study also showed a very high agreement between the outcomes of land use mapping based on the interpretation of aerial photos and those obtained through cadastral data, confirming that these data sources are well comparable from both a geometric and a thematic point of view. These evidences are consistent with numerous researches reported in literature about the usefulness of old cadastral maps as a reliable reference about past LULC settings [62,65]. However, we have highlighted the remarkable spatial accuracy characterizing the considered cadastral maps, which is mainly related to the high density of cadastral parcels. This is a peculiar feature of Ligurian cadastral maps which strongly depend on the high fragmentation of land ownerships among numerous smallholders together with the rugged morphology of this region. This aspect is particularly relevant in the Cinque Terre area [79], where cadastral parcels can be very small in size, sometimes hardly representable due to scale. In addition, the more detailed LULC information associated to cadastral data allowed to better refine the land use setting through the identification of the different types of crop. These aspects testify that old cadastral data may be very useful to address question on farmland abandonment in historical time. For example, such data could represent effective tools to recognize the location and the extent of terraces at a very detailed scale, also where they have been covered by dense vegetation or disrupted by geomorphological processes. In this regard, cadastral-based spatial information may be coupled with high-resolution remote sensing techniques such as light detection and ranging (LiDAR) [83].

The LULC change detection pointed out a loss of cultivated areas amounting to $77.4 \%$ over approximately sixty years. As a result, such land use changes severely influenced the effects of hydro-geomorphological phenomena in these areas, as evidenced by the rainfall-induced ground effects of the 25 October 2011 event. This research showed that 1954 agricultural areas were strongly affected by landslides both in terms of number and magnitude (Figure 7). As can be seen in Figure 7b, rainfall-induced landslides triggered on 1954 agricultural areas were more numerous (295-81\%) with respect to those triggered outside of them (69-19\%). Moreover, in terms of the area covered by landslides (Figure 7c), considering that the percentage of the overall basin area affected by slope failures was about 1.5\% [11], 75.2\% of the total landslide area is referred to 1954 agricultural areas. These observations testify that terraced areas are highly susceptible to slope instabilities in case of extreme rainfall. This is in agreement with the evidences reported by other researches performed both in the study area $[11,59,84-90]$ and in other terraced environments around the world [58,91-93]. As reported in technical literature, several factors can influence the occurrence of slope instabilities in terraced systems [58]. Some of these factors are related to the geometrical features of terraced slopes (e.g., height of dry-stone walls and slope steepness) [23] while in other cases they are directly associated 
to the hydrological functions of terraces. For example, the development of groundwater flows in response to the major water infiltration can lead to the saturation of backfill soils that in turn can cause a dangerous increase of pore water pressure with negative consequences on soil strength [32,91-93]. Other researchers outlined the disfunctions of the drainage systems (e.g., channels and ditches) [58] or the disturbance of dry-stone walls due to root growth as an important landslide predisposing agent. As reported by Cevasco et al. [11], within the study area the mass movements may have been favored by the permeability contrast between backfill soil and underlying bedrock that in turn may have promoted the formation of perched groundwater tables and seepage processes parallel to slope or upward directed. In this stratigraphic layout, sliding surfaces are often set at the interface between the retained soil and the bedrock $[11,57,93]$. The higher landslide susceptibility of terraced areas can be also attributed to the degree of maintenance of dry-stone masonries [53]. In the study area, the lack of maintenance can affect abandoned areas and to some extent also cultivated terraces [11].

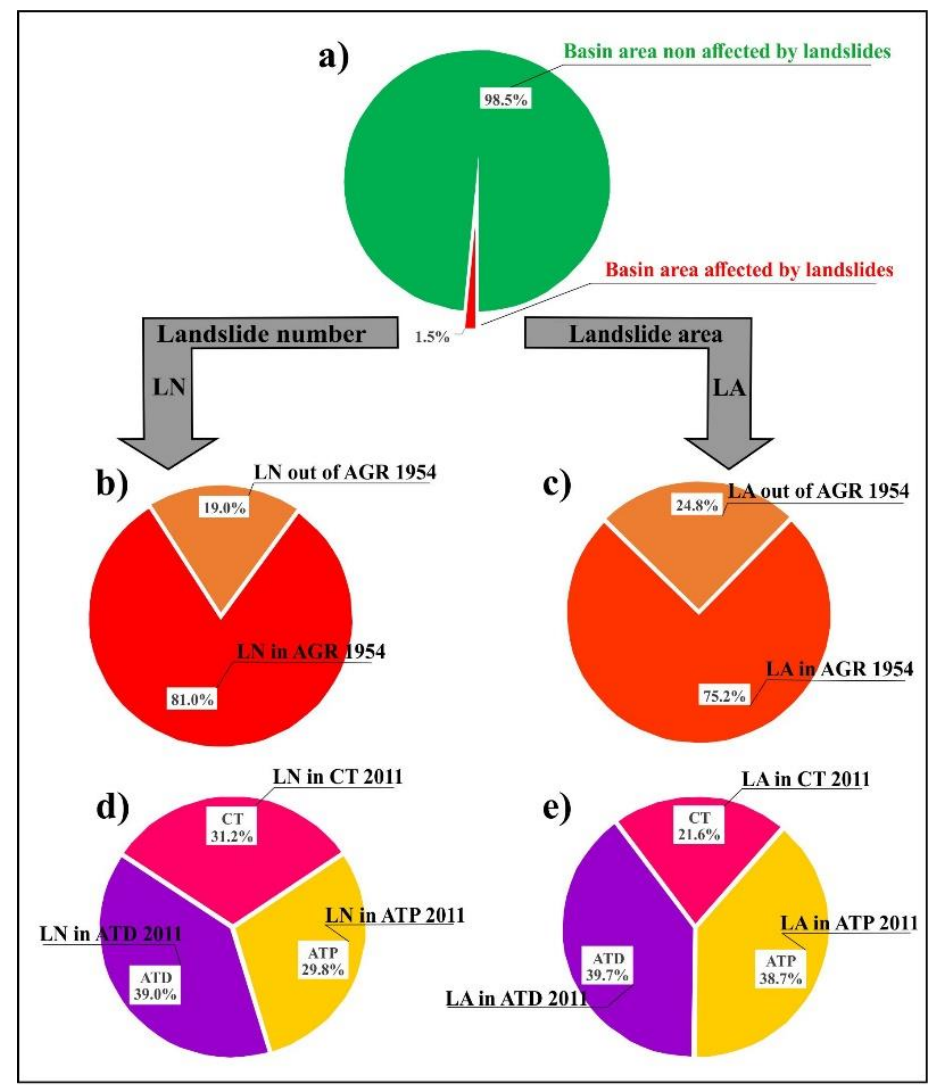

Figure 7. (a) Percentage of basin area affected by shallow landslides; (b) Percentage of landslides triggered in and out of AGR 1954; (c) Percentage of landslide area in and out of AGR 1954; (d) Percentage of landslides triggered in CT, ATP and ATD in 2011; (e) Percentage of landslide area in CT, ATP and ATD in 2011; LN, landslide number; LA, landslide area; AGR 1954, agricultural area of 1954; CT, cultivated terraced slopes; ATP, abandoned terraced slopes with poor cover; ATD, abandoned terraced slopes with dense cover.

This research clearly highlighted the negative role of farmland abandonment on rainfall-induced effects. The highest number of failure phenomena (68.8\%) was triggered on abandoned agricultural lands (Figure 7d). However, the landslide index values reveal that ATP are characterized by higher landslide susceptibility than cultivated terraced slopes and ATD, respectively. Therefore, these outcomes further strengthen the findings of previous researches indicating that abandoned slopes become more stable when colonized by dense vegetation and thus after longer time of abandonment $[59,94,95]$. Conversely, since recently abandoned terraces are poorly colonized by forest tree species, they do not 
benefit from the stabilizing effects of vegetation (e.g., contribution of anchorage by root systems of forest tree species), so landslides processes are more intense [59,96-98]. Therefore, the phase between the initiation of terrace abandonment and the development of the dense vegetation represents the most hazardous scenario. Interestingly, the percentage of landslide area in CT is considerably lower than one-third of the total landslide area while it is approximately half of the landslide area in ATP and ATD. By comparing Figure 7d with Figure 7e it can be inferred that despite the number of triggered landslides being significant also in CT (31.2\%, or 92 landslides), the corresponding landslide area $(21.6 \%)$ is smaller than ATD (39.7\%) and ATP (38.7\%), respectively. In this regard, this research showed that shallow landslides triggered on CT were on average characterized by lower magnitude than those occurred on ATP and ATD. This outcome is consistent with similar studies [59] and testifies the negative consequences induced by the cessation of terrace cultivation and maintenance on slope stability. It should be noted, however, that in the study area the high fragmentation of land ownerships can make difficult the maintenance of dry-stone walls. In this regard, cultivated areas can be often placed near or surrounded by abandoned properties, making the maintenance works on border dry-stone walls not possible to be carried out (Figure 8).

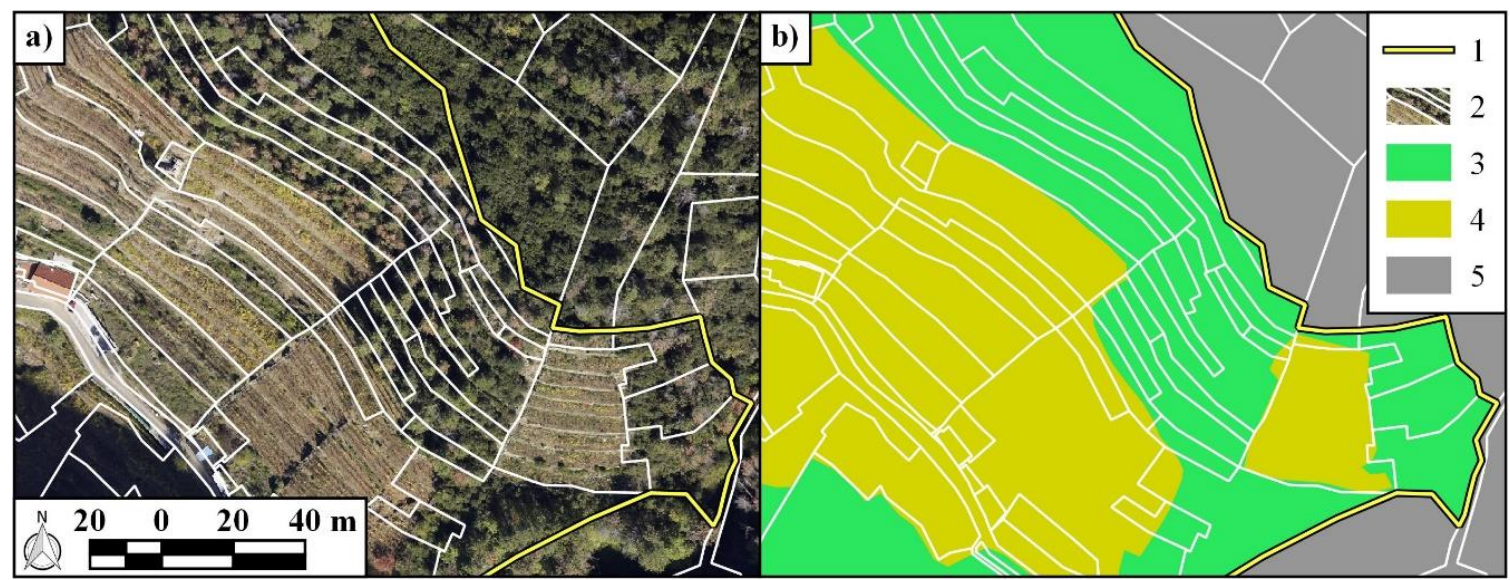

Figure 8. Comparison between the cadastral map and the 2011 orthophoto (a) and the 2011 LULC map (b). It can be noted the high fragmentation of land ownerships as well as the spatial accuracy of old cadastral data. 1, Boundary between the agricultural areas and the natural areas dated 1954; 2, parcel border; 3, abandoned terraced slope with dense cover (ATD); 4, cultivated vineyard (CTV); 5, natural and semi-natural area (NAT).

\section{Conclusions}

Farmland abandonment is a typical land use change commonly affecting hilly and mountainous zones worldwide. Terraced landscapes are extremely vulnerable territories, where crop abandonment can have extensive implications on the effects of hydrological and geomorphological processes, particularly in case of extreme rainfall events. In these peculiar landscapes, such effects represent a threat to slope stability and constitute an important source of risk when located in the proximity of urbanised areas.

This paper presented a quantitative multi-temporal analysis, performed in a GIS environment using different spatial information sources, aimed at investigating the LULC transformations that affected agricultural terraced slopes in a small coastal catchment and accurately estimating the degree of abandonment of terraces. In addition to this, the implications of such LULC modifications on the distribution, abundance, and magnitude of rainfall induced shallow landslides triggered by an intense rainstorm that occurred in 2011 were analysed.

It was observed that over the last sixty years extensive portions of agricultural terraced slopes have been abandoned and this has severely influenced the effects of shallow landsliding, producing negative consequences on slope stability. Since the selected study area is representative of farmland 
abandonment experienced by many rural territories of the entire Liguria region, our observations can support the scheduling of effective land management strategies. In this sense, we highlighted the usefulness of old cadastral data because of both the high spatial accuracy and thematic completeness of the associated database.

Eventually, the results of this research can be useful for future studies that address soil erosion and the shallow landslide susceptibility of terraced slopes by means of simulations of land use change scenarios.

Author Contributions: G.P. and A.M. have developed the conceptualization and the methodology of the study. A.M. performed GIS analysis. G.P. and A.M. have interpreted obtained results. G.P. written and managed the manuscript. E.R. and P.S. have contributed to data collection and discussion of results. A.C. and P.B. have supervised and coordinated the research activity and have provided their suggestions and revisions during the writing of the paper.

Funding: This research received no external funding.

Acknowledgments: The authors would like to thank Cinque Terre National Park for providing historical cadastral data of the study area. The authors wish to thank also three anonymous referees for their helpful comments and suggestions that improved this paper.

Conflicts of Interest: The authors declare no conflict of interest.

\section{References}

1. Van Westen, C.J.; Castellanos, E.; Kuriakose, S.L. Spatial data for landslide susceptibility, hazard, and vulnerability assessment: An overview. Eng. Geol. 2008, 102, 112-131. [CrossRef]

2. Corominas, J.; Van Westen, C.; Frattini, P.; Cascini, L.; Malet, J.P.; Fotopolou, S.; Catani, F.; Van Den Eeckhaut, M.; Mavrouli, O.; Agliardi, F.; et al. Recommendations for the quantitative analysis of landslide risk. Bull. Eng. Geol. Environ. 2014, 73, 209-263. [CrossRef]

3. Fohrer, N.; Haverkamp, S.; Eckhardt, K.; Frede, H.G. Hydrologic response to land use changes on the catchment scale. Phys. Chem. Earth Part B 2001, 26, 577-582. [CrossRef]

4. Gutierrez, F.; Gutierrez, M.; Sancho, C. Geomorphological and sedimentological analysis of a catastrophic flash flood in the Aràs drainage basin (central Pyrenees, Spain). Geomorphology 1998, 22, 265-283. [CrossRef]

5. Mandarino, A.; Maerker, M.; Firpo, M. The stolen space: A history of channelization, reduction of riverine areas and related management issues. The lower Scrivia River case study (NW Italy). Int. J. Sustain. Dev. Plan. 2019, 14, 118-129. [CrossRef]

6. Mandarino, A.; Maerker, M.; Firpo, M. Channel planform changes along the Scrivia River floodplain reach in northwest Italy from 1878 to 2016. Quat. Res. 2019, 91, 620-637. [CrossRef]

7. Glade, T. Landslide occurrence as a response to land use change: A review of evidence from New Zealand. Catena 2003, 51, 297-314. [CrossRef]

8. Tasser, E.; Mader, M.; Tappeiner, U. Effects of land use in alpine grasslands on the probability of landslides. Basic Appl. Ecol. 2003, 4, 271-280. [CrossRef]

9. Beguería, S. Changes in land cover and shallow landslide activity: A case study in the Spanish Pyrenees. Geomorphology 2006, 74, 196-206. [CrossRef]

10. Persichillo, M.G.; Bordoni, M.; Meisina, C. The role of land use changes in the distribution of shallow landslides. Sci. Total Environ. 2017, 574, 924-937. [CrossRef] [PubMed]

11. Cevasco, A.; Pepe, G.; Brandolini, P. The influences of geological and land use settings on shallow landslides triggered by an intense rainfall event in a coastal terraced environment. Bull. Eng. Geol. Environ. 2014, 73, 859-875. [CrossRef]

12. Galve, J.P.; Cevasco, A.; Brandolini, P.; Soldati, M. Assessment of shallow landslide risk mitigation measures based on land use planning through probabilistic modelling. Landslides 2015, 12, 101-114. [CrossRef]

13. Van Beek, L.P.H.; Van Asch, T.W. Regional assessment of the effects of land-use change on landslide hazard by means of physically based modelling. Nat. Hazards 2004, 31, 289-304. [CrossRef]

14. Gariano, S.L.; Petrucci, O.; Rianna, G.; Santini, M.; Guzzetti, F. Impacts of past and future land changes on landslides in southern Italy. Reg. Environ. Chang. 2018, 18, 437-449. [CrossRef]

15. Promper, C.; Puissant, A.; Malet, J.P.; Glade, T. Analysis of land cover changes in the past and the future as contribution to landslide risk scenarios. Appl. Geogr. 2014, 53, 11-19. [CrossRef] 
16. Malek, Ž.; Boerboom, L.; Glade, T. Future forest cover change scenarios with implications for landslide risk: An example from Buzau Subcarpathians, Romania. Environ. Manag. 2015, 56, 1228-1243. [CrossRef]

17. Greenway, D.R. Vegetation and slope stability, chapter 6. In Slope Stability; Anderson, M.G., Richards, K.S., Eds.; John Wiley and Sons Ltd.: West Sussex, UK, 1987; pp. 187-230.

18. Wilkinson, P.L.; Anderson, M.G.; Lloyd, D.M. An integrated hydrological model for rain-induced landslide prediction. Earth Surf. Proc. Landf. 2002, 27, 1285-1297. [CrossRef]

19. Kosmas, C.; Danalatos, N.; Cammeraat, L.H.; Chabart, M.; Diamantopoulos, J.; Farand, R.; Gutiérrez, M.; Jacob, A.; Marques, H.; Martinez-Fernandez, J.; et al. The effect of land use on runoff and soil erosion rates under Mediterranean conditions. Catena 1997, 29, 45-59. [CrossRef]

20. Crozier, M.J. Multiple-occurrence regional landslide events in New Zealand: Hazard management issues. Landslides 2005, 2, 247-256. [CrossRef]

21. García-Ruiz, J.M. The effects of land uses on soil erosion in Spain: A review. Catena 2010, 81, 1-11. [CrossRef]

22. Del Monte, M.; Vergari, F.; Brandolini, P.; Capolongo, D.; Cevasco, A.; Ciccacci, S.; Conoscenti, C.; Fredi, P.; Melelli, L.; Rotigliano, E.; et al. Multi-method evaluation of denudation rates in small Mediterranean catchments. In Engineering Geology for Society and Territory; Lollino, G., Manconi, A., Clague, J., Shan, W., Chiarle, M., Eds.; Springer International Publishing: Cham, Switzerland, 2015; Volume 1, pp. 563-567. [CrossRef]

23. García-Ruiz, J.M.; Lana-Renault, N. Hydrological and erosive consequences of farmland abandonment in Europe, with special reference to the Mediterranean region-A review. Agric. Ecosyst. Environ. 2011, 140, 317-338. [CrossRef]

24. Lasanta, T.; Nadal-Romero, E.; Arnáez, J. Managing abandoned farmland to control the impact of re-vegetation on the environment. The state of the art in Europe. Environ. Sci. Policy 2015, 52, 99-109. [CrossRef]

25. Diodato, N.; Soriano, M.; Bellocchi, G.; Fiorillo, F.; Cevasco, A.; Revellino, P.; Guadagno, F.M. Historical evolution of slope instability in the Calore River Basin, Southern Italy. Geomorphology 2017, 282, 74-84. [CrossRef]

26. Poyatos, R.; Latron, J.; Llorens, P. Land use and land cover change after farmland abandonment. The case of a Mediterranean Mountain area (Catalan Pre-Pyrenees). Mt. Res. Dev. 2003, 23, 362-368. [CrossRef]

27. Vicente-Serrano, S.; Lasanta, T.; Romo, A. Analysis of the spatial and temporal evolution of vegetation cover in the Spanish Central Pyrenees. The role of human management. Environ. Manag. 2005, 34, 802-818. [CrossRef] [PubMed]

28. MacDonald, D.; Crabtree, J.R.; Wiesinger, G.; Dax, T.; Stamou, N.; Fleury, P.; Gutierrez Lazpita, J.; Gibon, A. Agricultural abandonment in mountain areas of Europe: Environmental consequences and policy response. J. Environ. Manag. 2000, 59, 47-69. [CrossRef]

29. Cerdà, A. Soil erosion after land abandonment in a semiarid environment of Southeastern Spain. Arid Land Res. Manag. 1997, 11, 163-176. [CrossRef]

30. Agnoletti, M. The degradation of traditional landscape in a mountain area of Tuscany during the 19th and 20th centuries: Implications for biodiversity and sustainable management. For. Ecol. Manag. 2007, 249, 5-17. [CrossRef]

31. Koulouri, M.; Giourga, C. Land abandonment and slope gradient as key factors of soil erosion in Mediterranean terraced lands. Catena 2007, 69, 274-281. [CrossRef]

32. Arnáez, J.; Lasanta, T.; Errea, M.P.; Ortigosa, L. Land abandonment, landscape evolution, and soil erosion in a Spanish Mediterranean mountain region: The case of Camero Viejo. Land Degrad. Dev. 2011, 22, 537-550. [CrossRef]

33. Brandolini, P.; Pepe, G.; Capolongo, D.; Cappadonia, C.; Cevasco, A.; Conoscenti, C.; Marsico, A.; Vergari, F.; Del Monte, M. Hillslope degradation in representative Italian areas: Just soil erosion risk or opportunity for development? Land Degrad. Dev. 2018, 29, 3050-3068. [CrossRef]

34. Gioia, D.; Lazzari, M. Testing the Prediction Ability of LEM-Derived Sedimentary Budget in an Upland Catchment of the Southern Apennines, Italy: A Source to Sink Approach. Water 2019, 11, 911. [CrossRef]

35. Cevasco, A.; Diodato, N.; Revellino, P.; Fiorillo, F.; Grelle, G.; Guadagno, F.M. Storminess and geo-hydrological events affecting small coastal basins in a terraced Mediterranean environment. Sci. Total Environ. 2015, 532, 208-219. [CrossRef] 
36. Capolongo, D.; Diodato, N.; Mannaerts, C.; Piccarreta, M.; Strobl, R.O. Analyzing temporal changes in climate erosivity using a simplified rainfall erosivity model in Basilicata (southern Italy). J. Hydrol. 2008, 356, 119-130. [CrossRef]

37. Piccarreta, M.; Capolongo, D.; Boenzi, F.; Bentivenga, M. Implications of decadal changes in precipitation and land use policy to soil erosion in Basilicata, Italy. Catena 2006, 65, 138-151. [CrossRef]

38. Della Seta, M.; Del Monte, M.; Fredi, P.; Lupia Palmieri, E. Spacetime variability of denudation rates at the catchment and hillslope scales on the Tyrrhenian side of Central Italy. Geomorphology 2009, 107, 161-177. [CrossRef]

39. Piacentini, T.; Galli, A.; Marsala, V.; Miccadei, E. Analysis of soil erosion induced by heavy rainfall: A case study from the NE Abruzzo Hills Area in Central Italy. Water 2018, 10, 1314. [CrossRef]

40. Calista, M.; Miccadei, E.; Piacentini, T.; Sciarra, N. Morphostructural, Meteorological and Seismic Factors Controlling Landslides in Weak Rocks: The Case Studies of Castelnuovo and Ponzano (North East Abruzzo, Central Italy). Geosciences 2019, 9, 122. [CrossRef]

41. Carabella, C.; Miccadei, E.; Paglia, G.; Sciarra, N. Post-wildfire landslide hazard assessment: The case of the 2017 Montagna del Morrone fire (Central Apennines, Italy). Geosciences 2019, 9, 175. [CrossRef]

42. Pepe, G.; Mandarino, A.; Raso, E.; Cevasco, A.; Firpo, M.; Casagli, N. Extreme flood and landslides triggered in the Arroscia Valley (Liguria Region, Northwestern Italy) during the November 2016 rainfall event. In Slope Stability: Case Histories, Landslide Mapping, Emerging Technologies, Proceedings of the IAEG/AEG Annual Meeting Proceedings, San Francisco, CA, USA, 17-21 September 2018; Shakoor, A., Kato, K., Eds.; Springer International Publishing: Cham, Switzerland, 2019; Volume 1, pp. 171-175. [CrossRef]

43. Galve, J.P.; Cevasco, A.; Brandolini, P.; Piacentini, D.; Azañon, J.M.; Notti, D.; Soldati, M. Cost-based analysis of mitigation measures for shallow-landslide risk reduction strategies. Eng. Geol. 2016, 213, 142-157. [CrossRef]

44. Cevasco, A.; Pepe, G.; D'Amato Avanzi, G.; Giannecchini, R. Preliminary analysis of the November 10, 2014 rainstorm and related landslides in the lower Lavagna valley (eastern Liguria). Ital. J. Eng. Geol. Environ. 2017, 1, 5-15. [CrossRef]

45. Morgan, R.P.C. Soil Erosion and Conservation, 2nd ed.; Longman Group: Harlow, UK, 2015.

46. Stanchi, S.; Freppaz, M.; Agnelli, A.; Reinsch, T.; Zanini, E. Properties, best management practices and conservation of terraced soils in Southern Europe (from Mediterranean areas to the Alps): A review. Quat. Int. 2012, 265, 90-100. [CrossRef]

47. Li, X.H.; Yang, J.; Zhao, C.Y.; Wang, B. Runoff and sediment from orchard terraces in southeastern China. Land Degrad. Dev. 2014, 25, 184-192. [CrossRef]

48. Grove, A.T.; Rackham, O. The Nature of Mediterranean Europe: An Ecological History; Yale University Press: New Haven, CT, USA, 2003.

49. Cammeraat, L.H. Scale dependent thresholds in hydrological and erosion response of a semi-arid catchment in southeast Spain. Agric. Ecosyst. Environ. 2004, 104, 317-332. [CrossRef]

50. Gallart, F.; Llorens, P.; Latron, J.; Regüés, D. Hydrological processes and their seasonal controls in a smallMediterranean mountain catchment in the Pyrenees. Hydrol. Earth Syst. Sci. 2002, 6, 527-537. [CrossRef]

51. Tarolli, P.; Preti, F.; Romano, N. Terraced landscapes: From an old best practice to a potential hazard for soil degradation due to land abandonment. Anthropocene 2014, 6, 10-25. [CrossRef]

52. Gallart, F.; Llorens, P.; Latron, J. Studying the role of old agricultural terraces on runoff generation in a small Mediterranean mountainous basin. J. Hydrol. 1994, 159, 291-303. [CrossRef]

53. Camera, C.; Masetti, M.; Apuani, T. Rainfall, infiltration, and groundwater flow in a terraced slope of Valtellina (Northern Italy): Field data and modelling. Environ. Earth Sci. 2012, 65, 1191-1202. [CrossRef]

54. Lasanta, T.; Arnáez, J.; Oserin, M.; Ortigosa, L.M. Marginal lands and erosion in terraced fields in the Mediterranean mountains. A case study in the Camero Viejo (Northwestern Iberian System, Spain). Mt. Res. Dev. 2001, 21, 69-76. [CrossRef]

55. Brunori, E.; Salvati, L.; Antogiovanni, A.; Biasi, R. Worrying about 'Vertical Landscapes': Terraced Olive Groves and Ecosystem Services in Marginal Land in Central Italy. Sustainability 2018, 10, 1164. [CrossRef]

56. Lasanta, T.; Vicente-Serrano, S.M.; Cuadrat-Prats, J.M. Mountain Mediterranean landscape evolution caused by the abandonment of traditional primary activities: A study of the Spanish Central Pyrenees. Appl. Geogr. 2005, 25, 47-65. [CrossRef] 
57. Lesschen, J.P.; Cammeraat, L.H.; Nieman, T. Erosion and terrace failure due to agricultural land abandonment in a semi-arid environment. Earth Surf. Proc. Landf. 2008, 33, 1574-1584. [CrossRef]

58. Moreno-de-las-Heras, M.; Lindenberger, F.; Latron, J.; Lana-Renault, N.; Llorens, P.; Arnáez, J.; Romero-Díaz, A.; Gallart, F. Hydro-geomorphological consequences of the abandonment of agricultural terraces in the Mediterranean region: Key controlling factors and landscape stability patterns. Geomorphology 2019, 333, 73-91. [CrossRef]

59. Brandolini, P.; Cevasco, A.; Capolongo, D.; Pepe, G.; Lovergine, F.; Del Monte, M. Response of terraced slopes to a very intense rainfall event and relationships with land abandonment: A case study from Cinque Terre (Italy). Land Degrad. Dev. 2018, 29, 630-642. [CrossRef]

60. Lambin, E.F. Modelling and monitoring land-cover change processes in tropical regions. Prog. Phys. Geogr. 1997, 21, 375-393. [CrossRef]

61. Parcerisas, L.; Marull, J.; Pino, J.; Tello, E.; Coll, F.; Basnou, C. Land use changes, landscape ecology and their socioeconomic driving forces in the Spanish Mediterranean coast (El Maresme County, 1850-2005). Environ. Sci. Policy 2012, 23, 120-132. [CrossRef]

62. Hamre, L.N.; Domaas, S.T.; Austad, I.; Rydgren, K. Land-cover and structural changes in a western Norwegian cultural landscape since 1865, based on an old cadastral map and a field survey. Landsc. Ecol. 2007, 22, 1563-1574. [CrossRef]

63. Olarieta, J.R.; Rodriguez-Valle, F.L.; Tello, E. Preserving and destroying soils, transforming landscapes: Soils and land-use changes in the Valles County (Catalunya, Spain) 1853-2004. Land Use Policy 2008, 25, 474-484. [CrossRef]

64. Bender, O.; Boehmer, H.J.; Jens, D.; Schumacher, K.P. Using GIS to analyse long-term cultural landscape change in Southern Germany. Landsc. Urban Plan. 2005, 70, 111-125. [CrossRef]

65. Cousins, S.A. Analysis of land-cover transitions based on 17th and 18th century cadastral maps and aerial photographs. Landsc. Ecol. 2001, 16, 41-54. [CrossRef]

66. Falcucci, A.; Maiorano, L.; Boitani, L. Changes in land-use/land-cover patterns in Italy and their implications for biodiversity conservation. Landsc. Ecol. 2007, 22, 617-631. [CrossRef]

67. Raska, P.; Klimes, J.; Dubisar, J. Using local archive sources to reconstruct historical landslide occurrence in selected urban regions of the Czech Republic: Examples from regions with different historical development. Land Degrad. Dev. 2015, 26, 142-157. [CrossRef]

68. Brandolini, P.; Faccini, F.; Pescetto, C. I paesaggi terrazzati d'Italia. I terrazzamenti della Liguria: Un bene culturale e del paesaggio a rischio. L'Universo 2008, 88, 204-221.

69. Brancucci, G.; Paliaga, G. The Hazard Assessment in a Terraced Landscape: The Liguria (Italy) Case Study in the Interreg III Alpter Project. Geohazards_-Technical, Economical and Social Risk Evaluation; Berkeley Electronics Press: Berkeley, CA, USA, 2007; pp. 227-234.

70. Cevasco, A.; Pepe, G.; Brandolini, P. Shallow landslides induced by heavy rainfall on terraced slopes: The case study of the October, 25th, 2011 event in the Vernazza catchment (Cinque Terre, NW Italy). Rend. Online Soc. Geol. Ital. 2012, 21, 384-386.

71. Regione Liguria. Geoportale Regione Liguria. Liguria Region: Genova, Italy. Available online: https: //geoportal.regione.liguria.it (accessed on 26 July 2019).

72. Giammarino, S.; Giglia, G. Gli elementi strutturali della piega di La Spezia nel contesto geodinamico dell'Appennino Settentrionale. Boll. Soc. Geol. Ital. 1990, 109, 683-692.

73. Cevasco, A. I fenomeni di instabilità nell'evoluzione della costa alta delle Cinque Terre (Liguria Orientale). Studi Costieri 2007, 13, 93-109.

74. Brandolini, P. The outstanding terraced landscape of the Cinque Terre coastal slopes (eastern Liguria). In Landforms and Landscapes of Italy; Soldati, M., Marchetti, M., Eds.; Springer International Publishing: Cham, Switzerland, 2017; pp. 235-244.

75. Mastronuzzi, G.; Aringoli, D.; Aucelli, P.P.C.; Baldassarre, M.A.; Bellotti, P.; Bini, M.; Biolchi, S.; Bontempi, S.; Brandolini, P.; Chelli, A.; et al. Geomorphological map of the Italian coast: From a descriptive to a morphodynamic approach. Geogr. Fis. Din. Quat. 2017, 40, 161-196. [CrossRef]

76. Cevasco, A.; Pepe, G.; Brandolini, P. Geotechnical and stratigraphic aspects of shallow landslides at Cinque Terre (Liguria, Italy). Rend. Online Soc. Geol. Ital. 2013, 24, 52-54. 
77. Terranova, R.; Zanzucchi, G.; Bernini, M.; Brandolini, P.; Campobasso, S.; Faccini, F.; Renzi, L.; Vescovi, P.; Zanzucchi, F. Geology, geomorphology and wines in the Cinque Terre National Park (Liguria, Italy) [Geologia, geomorfologia e vini nel Parco Nazionale delle Cinque Terre (Liguria, Italia)]. Boll. Soc. Geol. Ital. 2006, 6, 115-128.

78. Cevasco, A.; Brandolini, P.; Scopesi, C.; Rellini, I. Relationships between geo-hydrological processes induced by heavy rainfall and land-use: The case of 25 October 2011 in the Vernazza catchment (Cinque Terre, NW Italy). J. Maps 2013, 9, 289-298. [CrossRef]

79. Galanti, Y.; Barsanti, M.; Cevasco, A.; D’Amato Avanzi, G.; Giannecchini, R. Comparison of statistical methods and multi-time validation for the determination of the shallow landslide rainfall thresholds. Landslides 2018, 15, 937-952. [CrossRef]

80. Terranova, R.; Brandolini, P.; Spotorno, M.; Rota, M.; Montanari, C.; Galassi, D.; Nicchia, P.; Leale, S.; Bruzzo, R.; Renzi, L.; et al. Patrimoni de Marjades a la Mediterrania Occidental. Una Proposta de Catalogaciò; Commissiò Europea DGX, Programa Raphael: Palma Di Mallorca, Spain, 2002; p. 243.

81. Terranova, R. Il paesaggio costiero agrario terrazzato delle Cinque Terre in Liguria. Studi Ric. Geogr. 1989, 12, 1-58.

82. Agnoletti, M.; Errico, A.; Santoro, A.; Dani, A.; Preti, F. Terraced Landscapes and Hydrogeological Risk. Effects of Land Abandonment in Cinque Terre (Italy) during Severe Rainfall Events. Sustainability 2019, 11, 235. [CrossRef]

83. Godone, D.; Giordan, D.; Baldo, M. Rapid mapping application of vegetated terraces based on high resolution airborne LiDAR. Geomat. Nat. Hazards Risk 2018, 9, 970-985. [CrossRef]

84. Schilirò, L.; Cevasco, A.; Esposito, C.; Scarascia Mugnozza, G. Shallow landslide initiation on terraced slopes: Inferences from a physically-based approach. Geomat. Nat. Hazards Risk 2018, 9, 295-324. [CrossRef]

85. Schilirò, L.; Cevasco, A.; Esposito, C.; Scarascia Mugnozza, G. Role of Land Use in Landslide Initiation on Terraced Slopes: Inferences from Numerical Modelling. In Advancing Culture of Living with Landslides, Diversity of Landslide Forms, Workshop on World Landslide Forum, Ljubljana, Slovenia, 29 May-2 June 2017; Mikoš, M., Casagli, N., Yin, Y., Sassa, K., Eds.; Springer: Cham, Switzerland, 2017; Volume 4, pp. 315-320. ISBN1 978-3-319-53484-8. ISBN2 978-3-319-53485-5. [CrossRef]

86. Zingaro, M.; Refice, A.; Giachetta, E.; D’Addabbo, A.; Lovergine, F.; De Pasquale, V.; Pepe, G.; Brandolini, P.; Cevasco, A.; Capolongo, D. Sediment mobility and connectivity in a catchment: A new mapping approach. Sci. Total Environ. 2019, 672, 763-775. [CrossRef]

87. Persichillo, M.G.; Bordoni, M.; Meisina, C.; Bartelletti, C.; Giannecchini, R.; D’Amato Avanzi, G.; Galanti, Y.; Barsanti, M.; Cevasco, A.; Brandolini, P.; et al. Remarks on the Role of Landslide Inventories in the Statistical Methods Used for the Landslide Susceptibility Assessment. In Advancing Culture of Living with Landslides, Diversity of Landslide Forms, Workshop on World Landslide Forum, Ljubljana, Slovenia, 29 May-2 June 2017; Mikoš, M., Tiwari, B., Yin, Y., Sassa, K., Eds.; Springer: Cham, Switzerland, 2017; pp. 759-766. [CrossRef]

88. Persichillo, M.G.; Bordoni, M.; Meisina, C.; Bartelletti, C.; Giannecchini, R.; D’Amato Avanzi, G.; Galanti, Y.; Cevasco, A.; Brandolini, P.; Galve, J.P.; et al. Shallow landslide susceptibility analysis in relation to land use scenarios. In Landslides and Engineered Slopes. Experience, Theory and Practice; Aversa, S., Cascini, L., Picarelli, L., Scavia, C., Eds.; Associazione Geotecnica Italiana: Rome, Italy, 2016; pp. 1605-1612, ISBN 978-1-138-02988-0. [CrossRef]

89. Bordoni, M.; Persichillo, M.G.; Meisina, C.; Cevasco, A.; Giannecchini, R.; D'Amato Avanzi, G.; Galanti, Y.; Bartelletti, C.; Brandolini, P.; Zizioli, D. Developing and testing a data-driven methodology for shallow landslide susceptibility assessment: Preliminary results. Rend. Online Soc. Geol. Ital. 2015, 35, 25-28. [CrossRef]

90. Raso, E.; Mandarino, A.; Pepe, G.; Di Martire, D.; Cevasco, A.; Calcaterra, D.; Firpo, M. Landslide Inventory of the Cinque Terre National Park, Italy. In Slope Stability: Case Histories, Landslide Mapping, Emerging Technologies, Proceedings of the IAEG/AEG Annual Meeting Proceedings, San Francisco, CA, USA, 17-21 September 2018; Shakoor, A., Kato, K., Eds.; Springer International Publishing: Cham, Switzerland, 2019; Volume 1, pp. 201-205. [CrossRef]

91. Arnáez, J.; Lana-Renault, N.; Lasanta, T.; Ruiz-Flaño, P.; Castroviejo, J. Effects of farming terraces on hydrological and geomorphological processes. A review. Catena 2015, 128, 122-134. [CrossRef]

92. Camera, C.; Apuani, T.; Masetti, M. Mechanisms of failure on terraced slopes: The Valtellina case (northern Italy). Landslides 2014, 11, 43-54. [CrossRef] 
93. Crosta, G.B.; Dal Negro, P.; Frattini, P. Soil slips and debris flows on terraced slopes. Nat. Hazard Earth Syst. 2003, 3, 31-42. [CrossRef]

94. Cammeraat, E.; van Beek, R.; Kooijman, A. Vegetation succession and its consequences for slope stability in SE Spain. Plant Soil 2005, 278, 135-147. [CrossRef]

95. Ruecker, G.; Schad, P.; Alcubilla, M.M.; Ferrer, C. Natural regeneration of degraded soils and site changes on abandoned agricultural terraces in Mediterranean Spain. Land Degrad. Dev. 1998, 9, 179-188. [CrossRef]

96. López-Vicente, M.; Poesen, J.; Navas, A.; Gaspar, L. Predicting runoff and sediment connectivity and soil erosion by water for different land use scenarios in the Spanish Pre-Pyrenees. Catena 2013, 102, 62-73. [CrossRef]

97. Bazzoffi, P.; Gardin, L. Effectiveness of the GAEC standard of cross compliance retain terraces on soil erosion control. Ital. J. Agron. 2011, 6, 43-51. [CrossRef]

98. Camera, C.; Djuma, H.; Bruggeman, A.; Zoumides, C.; Eliades, M.; Charalambous, K.; Abate, D.; Faka, M. Quantifying the effectiveness of mountain terraces on soil erosion protection with sediment traps and dry-stone wall laser scans. Catena 2018, 171, 251-264. [CrossRef]

(C) 2019 by the authors. Licensee MDPI, Basel, Switzerland. This article is an open access article distributed under the terms and conditions of the Creative Commons Attribution (CC BY) license (http://creativecommons.org/licenses/by/4.0/). 